\title{
STRATEGI PEMASARAN JASA PENDIDIKAN DALAM MENINGKATKAN NILAI JUAL MADRASAH ALIYAH RIYADUS SHOLIHIN MUSIRAWAS
}

\section{Irwan Fathurrochman}

Institut Agama Islam Negeri (IAIN) Curup

irwan@iaincurup.ac.id

\section{Endang}

Institut Agama Islam Negeri (IAIN) Curup

endang@gmail.com

\section{Dian Bastian}

Institut Agama Islam Negeri (IAIN) Curup dianbastiantito@gmail.com

\section{Meri Ameliya}

Institut Agama Islam Negeri (IAIN) Curup meriameliya23@gmail.com

\section{Ade Suryani}

Institut Agama Islam Negeri (IAIN) Curup ade5721@gmail.com

\section{ABSTRAK}

Strategi pemasaran jasa pendidikan madrasah di lembaga pendidikan Islam kini memiliki banyak tantangan. Pemasaran jasa pendidikan merupakan strategi peningkatan nilai jual madrasah yang merupakan elemen penting bagi kualitas serta kemajuan taraf pendidikan lembaga pendidikan Islam. Artikel ilmiah ini secara khusus membahas bagaimana strategi madrasah dalam meningkatkan nilai jual madrasah, serta bagaimana penerapan strategi pemasaran jasa pendidikan dalam meningkatkan nilai jual Madrasah Aliyah Riyadus Sholihin. Secara kritis penulis melakukan bagaimana maraknya pemasaran jasa pendidikan beranjak dari konsep awal madrasah sebagai lembaga penyedia layanan pendidikan Islam dan bukan sebagai lahan bisnis dalam dunia pendidikan. Madrasah sebagai penyedia layanan pendidikan perlu belajar dan memiliki gairah untuk meningkatkan kepuasan pelanggan karena pendidikan adalah proses belajar mengajar yang terus berkelanjutan. Pemasaran jasa pendidikan di madrasah tidak berarti komersialisasi, tetapi mengutamakan pendidikan yang berkualitas, dan memberikan layanan yang sangat baik kepada para pemangku kepentingan. Kepuasan kepada masyarakat yang dapat bermanfaat dalam meningkatkan titik penjualan madrasah. 
Kata kunci: jasa pendidikan, strategi pemasaran, bauran pemasaran, pendidikan madrasah, nilai jual madrasah

\begin{abstract}
The focus of this discussion is on the marketing strategy of madrasah education services in Islamic education institutions which now has many challenges in the current global era. Marketing education services is a strategy to increase the sale value of madrassas which is the most important element for the quality and progress of education at an Islamic educational institution. This paper will specifically discuss how madrasa strategies increase the sale value of madrassas and how the application of marketing services to improve the marketing value of madrassas in MA Riyadus Sholihin. Furthermore, this paper looks critically at how lively the marketing of education services has gone from the initial concept of madrasa as an institution providing Islamic education services and not as a business ground in the world of education. Madrasas as education service providers need to learn and have a passion for increasing customer satisfaction because education is an ongoing learning process. Marketing education services in madrasas does not mean commercialization, but prioritizing quality education, and providing excellent services to stakeholders. Satisfaction with the community can be beneficial in increasing madrasa "selling points".
\end{abstract}

Key Words: educational services, marketing strategy, marketing mix, madrasa education, madrasa selling points

\title{
PENDAHULUAN
}

Sekolah merupakan lembaga pendidikan nirbala yang bergerak dalam bidang jasa pendidikan. Selain itu kompetisi antar sekolah pun semakin ketat. Maka dalam hal ini penyelenggara pendidikan dituntut untuk kreatif dalam menggali keunikan dan keunggulan sekolahnya agar dibutuhkan dan diminati oleh pelanggan jasa Pendidikan (Asmani, 2015, p. 116).

Manajemen pemasaran bagi lembaga pendidikan (terutama madrasah) diperlukan seiring dengan adanya persaingan antar sekolah yang semakin atraktif. Pemasaran dibutuhkan bagi lembaga pendidikan dalam membangun citranya yang positif. Apabila lembaga atau sekolah memiliki citra yang baik di mata masyarakat, maka besar kemungkinan akan lebih mudah dalam mengatasi persaingan. Jadi, pemasaran merupakan suatu proses yang harus dilakukan oleh madrasah untuk memberikan kepuasan pada stakeholder dan masyarakat. Penekanan kepada pemberian kepuasan kepada stakeholder merupakan hal yang harus dilakukan oleh setiap lembaga, agar mampu bersaing (Muhaimim et al., 2011, p. 98).

Pemasaran tersebut dapat dilihat dari adanya berbagai upaya kreatif dan inovatif dari para penyelenggara pendidikan untuk menggali keunikan dan keunggulan dari sekolahnya agar semakin dibutuhkan dan diminati oleh para pengguna jasa pendidikan. Untuk menarik calon peserta didik diperlukan strategi pemasaran yang bukan saja menjual jasa pendidikan secara apa adanya melainkan bagaimana mendekatkan pendekatan sesuai dengan keinginan dan kepuasan konsumen. Sebuah lembaga yang ingin sukses untuk masa depan 
akan menghadapi persaingan, harus mempraktekkan pemasaran secara terus menerus (Alma, 2005, p. 199).

\section{METODE}

Jenis penelitian yang dilakukan adalah penelitian kualitatif, dengan lokasi penelitiannya di Madrasah Aliyah Riyadhus Sholihin. Dimana penelitian ini berusaha menjelaskan dan menguatkan mengenai data yang didapat dari hasil observasi pada pihak terkait. Kemudian, instrumen yang digunakan dalam hal ini peneliti menggunakan instrumen wawancara, dimana peneliti telah menyiapkan beberapa pertanyaan yang hendak diajukan pada narasumber. Kemudian tahapan wawancara ini dilakukan secara online, karena adanya pandemi Covid19 yang telah mengkhawatirkan banyak pihak, wawancara secara online dilakukan dalam rangka memutus rantai penyebaran penularan pandemi Covid19.

\section{HASIL DAN PEMBAHASAN \\ Konsep Strategi Pemasaran dalam Meningkatkan Nilai Jual di MA Riyadus Sholihin}

Setiap organisasi mempunyai strategi untuk mendukung aktivitas serta kelangsungan organisasinya, dimana strategi harus sesuai dengan keadaan dan kondisi masyarakat. Strategi adalah suatu program yang mendukung untuk mencapai suatu tujuan perusahaan (Amstrong, 2003, p. 41).

Strategi adalah pendekatan secara keseluruhan yang berkaitan dengan pelaksanaan gagasan, perencanaan, dan eksekusi sebuah aktivitas dalam kurun waktu tertentu. Di dalam strategi yang baik terdapat koordinasi tim kerja, memiliki tema, mengidentifikasi faktor pendukung yang sesuai dengan prinsip-prinsip pelaksanaan gagasan rasional, efisien dalam pendanaan, dan memiliki taktik untuk mencapai tujuan secara efektif (Mundir, 2015).

Menurut Bitte, strategi adalah suatu rencana yang fundamental untuk mencapai tujuan perusahaan (Alma, 2005, p. 199). Sedangkan dalam KBBI, diartikan sebagai suatu rencana cermat mengenai kegiatan untuk mencapai sasaran khusus. Sementara itu strategi didefinisikan juga sebagai sebuah rencana yang komprehensif mengintegrasikan segala sumber daya dan kapabilitas yang mempunyai tujuan jangka panjang untuk memenangkan kompetisi (Sagala, 2007, p. 137).

Strategi dipandang sebagai sebuah program yang meliputi tujuan yang ingin dicapai, disertai dengan tindakan atau langkah-langkah khusus untuk mencapai tujuan tersebut sebagai usaha merespon lingkungannya. Para ahli mengemukakan pengertian secara berbeda-beda dalam penyajian dan pelaksanaannya, namun semuanya mempunyai pengertian yang hampir sama antara satu dengan yang lain. Berikut beberapa definisi mengenai pemasaran yang dimaksud. Menurut The American Marketing Association menyebutkan bahwa "marketing is the planning and executing the conception, pricing, promotion and distribution of ideas, goods and services to create exchanges that satisfiy individual and organizational goals" (Hooley et al., 2008, p. 7).

Definisi diatas mengandung arti bahwa pemasaran adalah suatu proses perencanaan dan menjalankan konsep, harga, promosi dan distribusi sejumlah 
ide, barang, dan jasa untuk menciptakan pertukaran yang mampu memuaskan tujuan individu dan organisasi.

Sedangkan menurut Chartered Institute Of Marketing,menyebutkan bahwa pemasaran adalah "management process of anticipating, identifying and satisfying customer requirements profitably" (Giligan \& Wilson, 2009, p. 1). Tersirat bahwa pemasaran adalah suatu proses manajemen yang bertanggung jawab untuk mengenali, mengantisipasi dan memuaskan keinginan dan kebutuhan pembeli demi meraih laba.

Selain itu Stanton mendefinisikan pemasaran adalah suatu system keseluruhan dari kegiatan-kegiatan bisnis yang ditujukan untuk merencanakan, menentukan harga, mempromosikan, dan mendistribusikan barang dan jasa yang memuaskan kebutuhan baik kepada pembeli yang ada maupun pembeli potensial (Swastha \& Irawan, 2008, p. 5).

Kotler dan Keller mengartikan bahwa marketing is a sociental prosess by with individuals and groups obtain what they need and want through creating, offering, and freely exchanging products and services of value with others (Kotler \& Kevin, 2012, p. 5). Pemasaran adalah suatu proses social dan manajerial dimana individu dan kelompok memperoleh apa yang mereka butuhkan dan inginkan dengan menciptakan, menawarkan dan secara bebas mempertukarkan produk dan jasa bernilai dengan pihak lain.

Dalam kaitannya dengan pemasaran, strategi didefinisikan sebagai alat fundamental yang direncanakan untuk mencapai tujuan perusahaan dengan mengembangkan keunggulan bersaing yang berkesinambungan melalui pasar yang dimasuki dan program pemasaran yang digunakan untuk melayani pasar sasaran (Sudiarta, 2011).

Dengan demikian, strategi pemasaran merupakan suatu rencana yang diformulasikan secara sistematis mengenai kegiatan pemasaran untuk dijadikan sebagai pedoman dalam kaitannya dengan implementasi variable-variabel pemasaran seperti identifikasi pasar, segmentasi pasar, pemosisian terhadap pasar dan elemen bauran pemasaran (Faizin, 2017).

\section{Jenis-Jenis Strategi Pemasaran}

Strategi pemasaran pada dasarnya merupakan rencana yang menyeluruh serta terpadu dan menyatu dibidang pemasaran barang dan jasa. Dengan perkataan lainnya strategi pemasaran itu adalah serangkaian tujuan dan sasaran kebijakan, serta aturan yang memberi arah kepada usaha-usaha pemasaran barang dan jasa. Strategi pemasaran juga merupakan wujud rencana yang terarah dibidang pemasaran, untuk memperoleh suatu hasil yang optimal.

Strategi pemasaran menurut Kotler merupakan pendekatan pokok yang akan digunakan oleh unit bisnis dalam mencapai sasaran yang telah ditetapkan terlebih dahulu, didalamnya tercantum keputusan-keputusan pokok mengenai target pasar, penempatan produk di pasar, bauran pemasaran barang, dan tingkat biaya pemasaran yang diperlukan (Kotler, 2000, p. 109). Definisi ini memberikan pemahaman pemasaran sebagai suatu proses sosial dan manajerial dimana individu dan kelompok mendapatkan kebutuhan dan keinginan mereka dengan menciptakan, menawarkan, dan bertukar sesuatu yang bernilai satu dengan lainnya. Sementara ini menurut Winardi menyatakan 
bahwa strategi pemasaran yang digunakan oleh perusahaan merupakan hasil dipadukannya berbagai elemen pemasaran (Winardi, 2001, p. 93).

Untuk mengetahui jenis strategi pemasaran mana yang tepat dan sesua dengan sebuah organisasi, perlu terlebih dahulu mengetahui jenis dan bentuk kebutuhan konsumen (pengguna), sebelum organisasi memasarkan produk yang dihasilkan. Strategi pemasaran dapat dibagi kedalam empat jenis dasar, yaitu pertama, merangsang kebutuhan primer dengan menambah jumlah pemakai. Kedua yaitu merangsang kebutuhan primer dengan memperbesar tingkat pembeli. Ketiga yaitu merangsang kebutuhan selektif dengan mempertahankan pelayanan yang ada. Dan keempat adalah merangsang kebutuhan selektif dengan menjaring pelanggan yang ada (Tedjasatesan, 2001).

Sementara itu Anam mengatakan bahwa strategi pemasaran terdiri dari dua strategi. Pertama yaitu strategi kebutuhan primer, strategi ini dirancang terutama untuk menaikan tingkat permintaan akan bentuk atau kelas produk dari bukan pemakaian sekarang (yang tidak ada atau hanya mempunyai sedikit pesaing saja) serta produk-produk dengan bagian pasar yang besar kemungkinan akan mendapat manfaat dari strategi yang dirancang untuk meningkatkan jumlah pemakai bentuk produk. Kedua yaitu strategi kebutuhan selektif, strategi ini dirancang untuk memperbaiki posisi pesaing suatu produk, jasa atau bisnis. Fokus dasar dari strategi-strategi ini adalah pada bagian pasar, karena perolehan penjualan diharapkan akan dating dengan mengembangkan bentuk produk satu kelas pesaing. Strategi kebutuhan selektif dapat dicapai dengan mempertahankan pelanggan lama atau dengan menyaring pelanggan baru (Anam, 2013).

\section{Bauran Pemasaran Jasa Pendidikan}

Jasa merupakan seluruh aktifitas ekonomi dengan output selain produk dalam pengertian fisik, dikonsumsi dan diproduksi pada saat bersamaan, memberikan nilai tambah dan secara prinsip tidak berwujud bagi pembeli pertamanya. Kotler merumuskan jasa adalah segala aktifitas atau manfaat yang dapat ditawarkan satu pihak kepada pihak lain yang pada dasarnya tidak berwujud, dan tidak menghasilkan kepemilikan apapun (Alma, 2005, p. 3).

Merujuk pengertian tersebut, ada lima ciri utama dalam setiap jasa yang dikutip dari pernyataan Bitner dkk serta Tadepali dan Hayes, yaitu pertama tidak berwujud (intangibility), sehingga konsumen tidak dapat melihat, mencium, meraba, mendengar dan merasakan hasilnya sebelum mereka membelinya. Untuk mengurangi ketidakpastian, maka konsumen mencari informasi tentang jasa tersebut. Sesuatu yang bisa di lihat itu bisa berupa kinerja guru, tata usaha, karyawan, sarana prasarana, peralatan pendidikan sekolah, simbol-simbol yang digunakan sekolah, juga biaya yang bisa mereka bayar ke sekolah. Kedua adalah tidak terpisahkan (inseparability), dimana jasa tidak dapat dipisahkan dari sumbernya yaitu perusahaan jasa. Ketiga adalah bervariasi (variability), dimana jasa sering kali berubah-ubah tergantung siapa, kapan dan dimana menyajikannya. Keempat yaitu mudah musnah (perishability), jasa tidak dapat di jual pada masa yang akan dating. Dan kelima adalah kepemilikan (ownership), karakteristik ini adalah karakteristik yang paling menantang. Siswa membayar biaya pendidikan di muka, dimana pada awalnya mereka tidak mendapat kepemilikan investasi pendidikan apapun. Akan tetapi mereka dapat menerima 
salah satu fasilitas, yaitu kartu perpustakaan. Dengan demikian siswa memiliki hak untuk mengakses perpustakaan ketika menunjukkan kartu perpustakaan kepada petugas perpustakaan (Alma, 2005).

Dalam dunia pendidikan, bahan baku untuk menghasilkan jasa ialah orang yang memiliki ciri khas yang berbeda antara satu dengan yang lainnya. Pepatah mengatakan bahwa tidak ada manusia yang memiliki persamaan bahkan anak kembar sekalipun. Hal itulah yang menjadikan dasar bahwa pelayanan jasa pendidikan antara satu dengan yang lainnya berbeda. Dengan melihat karakteristik tersebut, maka jasa pendidikan diterima setelah melakukan interaksi dengan penghubung yang sangat dipengaruhi oleh siapa, kapan dan dimana jasa tersebut diproduksi. Hal itu menjelaskan bahwa keberhasilan pendidikan akan sangat tergantung pada siapa, kapan dan dimana proses tersebut terlaksana.

Beberapa hal yang akan dilakukan lembaga pendidikan untuk meningkatkan calon pengguna jasa pendidikan adalah meningkatkan visualisasi jasa yang tidak berwujud menjadi berwujud, menekankan pada manfaat yang akan diperoleh (Iulusan lembaga pendidikan), dan menciptakan atau membangun suatu nama merek lembaga pendidikan (education brand name) (Mundir, 2015).

Dalam kaitannya dengan pendidikan, jasa dapat didefinisikan sebagai kegiatan lembaga pendidikan memberi layanan atau menyampaikan jasa pendidikan kepada konsumen dengan cara memuaskannya. Pemasaran dalam konteks jasa pendidikan adalah sebuah proses sosial dan manajerial untuk mendapatkan apa yng dibutuhkan dan diinginkan melalui penciptaan penawaran, pertukaran produk yang bernilai dengan pihak lain dalam bidang pendidikan. Etika pemasaran dalam dunia pendidikan adalah menawarkan mutu layanan intelektual dan pembentukan watak secara menyeluruh. Hal ini karena pendidikan bersifat lebih komplek, yang dilaksanakan dengan penuh tanggung jawab, hasil pendidikan mengacu jauh kedepan, membina kehidupan warga negara, generasi penerus ilmuan dimasa yang akan dating (Faizin, 2017).

Untuk keberhasilan sebuah lembaga dalam jangka panjang, maka lembaga tersebut harus menciptakan layanan yang memuaskan need and want pelanggannya. Guna menciptakan layanan yang memuaskan ini, maka lembaga menciptakan bauran pemasaran. Bauran pemasaran (marketing mix) merupakan unsur-unsur pemasaran yang saling terkait, dibaurkan, diorganisir dan digunakan dengan tepat sehingga perusahaan dalam mencapai tujuan pemasaran dengan efektif, sekaligus memuaskan kebutuhan dan keinginan konsumen (Hurriyati, 2010, p. 48).

Unsur-unsur yang terdapat dalam bauran pemasaan ada tujuh hal yang biasa disingkat dengan 7P yaitu terdiri dari 4P tradisional yang digunakan dalam pemasaran barang dan 3P sebagai perluasan bauran pemasaran jasa. Unsur 4P tersebut adalah product (produk) yaitu jasa seperti apa yang ditawarkan, price (harga) yaitu strategi penentuan harga, place (lokasi/tempat) yaitu dimana tempat jasa diberikan, promotion (promosi) yaitu bagaimana promosi dilakukan. Sedangkan unsur 3P adalah people (SDM) yaitu kualitas, kualifikasi, dan kompetensi yang dimiliki oleh orang-orang yang terlibat dalam pemberian jasa, physical evidence (bukti fisik) yaitu sarana-prasarana seperti apa yang dimilki, 
dan process yaitu manajemen layanan pembelajaran yang diberikan (Zeithaml et al., 2013).

\section{Penerapan Strategi Pemasaran Jasa Pendidikan dalam Meningkatkan nilai Jual Madrasah Aliyah Riyadus Sholihin Musirawas}

Fokus dari penerapan pemasaran ini adalah bagaimana mendekatkan pelayanan sesuai dengan keinginan dan kepuasan siswa, yang tentunya hal tersebut harus didukung dengan peran para tenaga ahli di bidangnya, sumber daya dan fasilitas yang memadai, serta selalu meningkatkan mutu lulusan. Hal itu meliputi planning (perencanaan), identifikasi pasar (pesaing), segmentasi pasar dan positioning, diferensiasi produk, organizing (pengorganisasian), actuating (penggerakan), dan controlling (pengendalian) (Minarti, 2012).

Planning atau perencanaan merupakan langkah pertama yang harus dilakukan seorang manajer. Fungsi planning mencakup mendefinisikan tujuan organisasi, mengembangkan strategi menyeluruh untuk mencapai tujuan dan mengembangkan dan mengordinasikan kegiatan untuk mencapai tujuan yang diharapkan. Perencanaan dalam pemasaran pendidikan bertujuan untuk mengurangi atau mengimbangi ketidakpastian dan perubahan yang akan datang, memusatkan perhatian kepada sasaran, menjamin atau mendapatkan proses pencapaian tujuan terlaksana secara efisien dan efektif, serta memudahkan pengendalian.

Tahapan pertama dalam pemasaran pendidikan adalah mengidentifikasi dan menganalisis pasar. Yakni mengidentifikasi dan menganalisis pasar untuk mengetahui kondisi dan ekspektasi pasar termasuk atribut-atribut pendidikan yang menjadi kepentingan konsumen pendidikan. Dalam hal ini sesungguhnya madrasah memiliki potensi yang tinggi dalam upaya ikut mencerdaskan bangsa dan mensukseskan program wajib belajar nasional (Khasanah, 2015).

Keberhasilan bisnis salah satunya ditentukan oleh kemampuan memahami pesaing. Output dari kemampuan tersebut menopang manajemen dalam memutuskan dimana akan bersaing dan bagaimana posisi diantara pesaing. Analisis dilakukan dengan cara identifikasi industri dan karakteristiknya, identifikasi bisnis di dalam industri, kemudian masing-masing bisnis pun dievaluasi, prediksi aktifitas pesaing termasuk identifikasi pesaing baru yang mungkin menerobos pasar maupun segmen pasar.

Analisis persaingan merupakan sebuah usaha untuk mengidentifikasi ancaman, kesempatan, atau permasalahan strategis yang terjadi sebagai akibat dari perubahan persaingan potensial, serta kekuatan dan kelemahan pesaing. Analisis persaingan merupakan aktifitas yang terus menenrus dan memerlukan koordinasi informasi. Bisnis dan unit bisnis menganalisis pesaing dapat dengan cara menggunakan sistem intelejen pesaing.

Tahapan kedua yaitu segmentasi pasar adalah membagi pasar menjadi kelompok pembeli yang dibedakan berdasarkan kebutuhan, karakteristik, atau tingkah laku, yang mungkin membutuhkan produk yang berbeda. Sedangkan positioning adalah karakteristik dan pembedaan (diferensiasi) produk yang nyata dan memudahkan konsumen untuk membedakan produk jasa antara satu lembaga dengan lembaga lainnya. Penentuan target pasar merupakan langkah penting dalam pengelolaan lembaga pendidikan. Dalam pasar yang sangat beragam karakternya, perlu ditentukan atribut-atribut apa yang menjadi 
kepentingan utama bagi pengguna pendidikan. Secara umum, pasar dapat dipilah berdasarkan karakteristik demografi, gografi, psikografi, maupun perilaku (Minarti, 2012, p. 395). Dengan demikian, sekolah akan lebih mudah menentukan strategi pemasaran sehubungan dengan karakteristik dan kebutuhan pasar. Setelah diketahui karakter pasar, maka akan menentukan bagian pasar mana yang akan dilayanai.

Tahap berikutnya adalah melakukan diferensiasi, yaitu merupakan cara yang efektif dalam mencari perhatian pasar. Dari banyaknya lembaga pendidikan yang ada, orang tua siswa akan kesulitan untuk memilih sekolah anaknya dikarenakan atribut-atribut kepentingan antar lembaga pendidikan semakin standar. Lembaga pendidikan hendaknya dapat memberikan tekanan yang berbeda dari sekolah lainnya dalam bentuk kemasan yang menarik, seperti logo dan slogan. Fasilitas internet mungkin akan menjadi standar, namun jaminan internet yang aman dan bersih, akan menarik perhatian orang tua (Minarti, 2012, p. 396).

Melakukan pembedaan secara mudah dapat pula dilakukan melalui bentuk-bentuk tampilan fisik yang tertangkap oleh panca indra yang memberikan kesan baik, seperti pemakaian seragam yang menarik dan geudng sekolah yang bersih. Strategi diferensiasi akan menempatkan organisasi secara unik untuk memenuhi kebutuhan khusus pelanggan. Terdapat empat cara difernsiasi, yaitu diferensiasi produk, diferensiasi layanan, diferensiasi karyawan, dan diferensiasi citra. Diferensiasi produk, yaitu membedakan penawaran produk dalam hal bentuk, ukuran, warna, daya tahan, kinerja, kemudahan dalam perawatannya, desain, dan sejenisnya. Diferensiasi layanan, yaitu membedakan penawaran dengan memberikan layanan yang unggul dalam hal pengantaran, kemudahan melakukan pesanan, pemasangan atau instalasi, perawatan pasca pemasangan, dan sejenisnya. Diferensiasi karyawan, yaitu membedakan penawaran dengan memiliki karyawan yang memiliki kemampuan atau kompetensi yang unggul dalam sikap yang ramah, sopan, gesit, selalu siap membantu, dan komunikatif. Diferensiasi citra, yaitu membedakan penawaran dengan memiliki citra produk dan citra perusahaan yang tinggi, yang bisa diwujudkan melalui symbol, penggunaan media komunikasi, atau peristiwa yang didukungnya (Suprapti, 2010, p. 47).

Tahap berikutnya adalah organizing, yaitu merupakan tanggung jawab menajer untuk mendesain struktur organisasi dan mengatur pembagian pekerjaan. Termasuk mempertimbangkan terus apa yang harus dilakukan, siapa yang melakukan, bagaimana tugas dikelompokkan, siapa melapor kepada siapa dan dimana keputusan dibuat (Wibowo, 2006, p. 12). Jadi dalam hal ini diperlukan suatu struktur yang jelas, sehingga tidak terjadi saling lempar tanggung jawab seandainya terjadi penyimpangan dalam pekerjaan. Pengorganisasian ini sebagai proses membagi kerja ke dalam tugas-tugas yang lebih kecil, membebankan tugas-tugas ini kepada orang yang sesuai dengan kemampuannya dan mengalokasikan sumber daya, serta mengkoordinasikannya dalam rangka efektivitas pencapaian tujuan organisasi (Fattah, 2017, p. 71).

Tahap berikutnya adalah actuating berkenaan dengan fungsi manajer untuk menjalankan tindakan dan melaksanakan pekerjaan yang diperlakukan untuk mencapai tujuan yang ingin dicapai oleh organisasi. Actuating merupakan 
implementasi dari apa yang direncanakan dalam fungsi planning dengan memanfaatkan persiapan yang sudah dilakukan dalam organizing (Wibowo, 2006, p. 13). Mengenai implementasi pemasaran, dalam merencanakan strategi yang baik hanyalah sebuah langkah awal menuju pemasaran sukses. Strategi pemasaran yang brilian kurang berarti apabila perusahaan gagal mengimplementasikannya dengan tepat. Implementasi pemasaran adalah proses yang mengubah strategi dan rencana menjadi tindakan pemasaran dalam rangka mencapai tujuan pemasaran stratejik.

Tahap terakhir yaitu controlling. Hal ini merupakan suatu aktivitas untuk meyakinkan bahwa semua hal berjalan seperti seharusnya dan memonitor kinerja organisasi (Wibowo, 2006, p. 14). Kontrol harus dilakukan sedini mungkin agar tidak terjadi kesalahn yang berlarut-larut. Untuk mencapai konrol yang baik, madrasah membutuhkan informasi yang cukup akurat dan memadai. Informasi yang telah di dapat, digunakan sebagai acuan dalam pelaksanaan kontrol dan evaluasi. Ada tiga jenis kontrol pemasaran yang dapat digunakan oleh madrasah, yaitu pertama rencana kontrol tahunan, yang meliputi monitoring pada kinerja pemasaran yang berlangsung untuk meyakinkan bahwa volume penjualan tahunan dan keuntungan yang ditargetkan tercapai. Kedua yaitu control profitabilitas, terdiri dari determinasi profitabilitas yang aktual dari pemasaran yang telah dilakukan, misalkan kesesuaian layanan yang telah ada dengan kebutuhan yang ada di masyarakat, segmen pasar, saluran promosi dan sebagainya. Ketiga yaitu sudit pemasaran, yang bertujuan untuk menganalisis tujuan pemasaran, strategi dan sistem yang didapati secara optimum dan lingkungan tujuan pemasaran yang telah diramalkan (Hafidhuddin \& Tanjung, 2003, p. 158). Adanya pelaksanaan sistem kontrol ini merupakan tindakan koreksi yang dapat digunakan baik untuk jangka pendek maupun jangka panjang. Meskipun begitu, kontrol dan evaluasi secara rutin harus dilaksanakan agar kesalahan yang telah dilakukan oleh madrasah dapat cepat diperbaiki dan antisipasi selanjutnya dapat dilakukan dengan cepat untuk perkembangan madrasah.

\section{Nilai Jual Madrasah}

Madrasah adalah sebuah lembaga sektor publik dalam satu pranata sosial yang menyediakan jasa pendidikan bagi masyarakat. Di Indonesia, pendidikan merupakan amanah yang menjadi tanggung jawab negara seperti telah diamanatkan dalam Pembukaan Undang-Undang Dasar 1945 (UUD 1945), yaitu bahwa tujuan pembentukan Pemerintah Negara Indonesia adalah melindungi segenap Bangsa Indonesia dan seluruh tumpah darah Indonesia dan untuk memajukan kesejahteraan umum, mencerdaskan kehidupan bangsa, dan ikut melaksanakan ketertiban dunia yang berdasarkan kemerdekaan, perdamaian abadi dan keadilan sosial.

Rendahnya alasan akademik yang dijadikan dasar bagi orang tua untuk memilih madrasah sesungguhnya merupakan tantangan bagi manajemen madrasah dan semua stakeholder yang terkait dengan madrasah agar dapat memperluas dan meningkatkan pemasaran madrasah. Madrasah dapat dipasarkan manakala mampu menunjukkan kualitas akademik yang dapat dipertanggungjawabkan. Apabila hal tersebut yang dikehendaki, maka madrasah tidak dapat lagi bertahan dengan paradigma klasiknya dalam pengelolaan 
madrasah, cara-cara konservatif dan jauh dari citra akademik mesti ditinggalkan. Perlu dilakukan langkah strategis dalam mengelola madrasah, cara tradisonal dan konvensional tidak dapat lagi bertahan dengan paradigma klasiknya dalam pengelolaan madrasah. Justru sebaliknya, madrasah mesti dikelola secara profesional dengan manajemen yang modern, senantiasa konsen terhadap mutu, dan memperhatikan kebutuhan, harapan, dan kepuasan orang tua, serta semua stakeholders.

Cara pandang masyarakat yang respek terhadap peningkatan mutu, serta kecenderungan dunia yang terlibat dalam jaringan pasar global, para pengelola madrasah dituntut kemampuannya untuk mampu menjual (memasarkan) madrasah yang dikelolanya. Dalam skala yang lebih luas, madrasah harus mampu masuk dalam bursa kompetisi pasaran pendidikan. Di negara-negara maju, manajemen pemasaran merupakan hal yang diperhatikan dalam berbagai organisasi. Di dalam sektor nirlaba menegaskan bahwa universitas yang menghadapi menurunnya jumlah pendaftar serta meningkatnya, sekarang menggunakan pemasaran untuk mencari mahasiswa dan dana. Mereka menetapkan pasar sasaran mereka dengan lebih jelas, memperbaiki komunikasi dan promosi, serta menanggapi kebutuhan dan keinginan mahasiswa dengan baik (Kotler, 1997, p. 37).

Suatu bentuk pergeseran yang dihadapi dalam dunia pendidikan. Artinya, pemasaran dalam dunia pendidikan sudah merupakan suatu keharusan. Dalam dunia pendidikan, pemasaran dapat diadopsi sebagai suatu proses kegiatan kependidikan untuk menempatkan lembaga pendidikan sebagai komoditas yang menyediakan jasa pelayanan bagi masyarakat. Terdapat dua elemen penting dalam upaya memasarkan lembaga pendidikan. Pertama adalah baiknya kualitas komunikasi dan promosi sebuah lembaga pendidikan. Kedua adalah kemampuan untuk menanggapi kebutuhan dan keinginan pelanggan dengan baik dalam kaitannya dengan pemenuhan kebutuhan pelayanan. Strategi pemasaran yang tepat akan dapat meningkatkan minat calon konsumen. Meningkatnya minat calon konsumen ini diharapkan akan meningkatkan jumlah siswa yang mendaftar ke madrasah tersebut. Banyaknya siswa yang mendaftar akan memungkinkan madrasah untuk melakukan seleksi dengan hanya memilih calon siswa yang potensial untuk berhasil.

\section{SIMPULAN}

Madrasah Aliyah Riyadus Sholihin Musirawas dalam upaya meningkatkan eksistensi dan citra lembaga pendidikan, telah menerapkan strategi-strategi yang optimal, oleh karena itu hendaknya para pengelola pendidikan lainnya dapat menerapkan konsep strategi pemasaran jasa pendidikan. Pemasaran jasa pendidikan merupakan langkah pembaruan lembaga pendidikan dalam rangka memasarkan produk layanan jasa pendidikan kepada masyarakat dengan menciptakan dan menawarkan inovasi produk jasa yang sesuai dengan harapan dan tuntunan pasar. Tujuan dalam pendidikan adalah memberi informasi kepada masyarakat tentang produk-produk lembaga pendidikan, meningkatkan minat dan ketertarikan masyarakat pada produk lembaga pendidikan, membedakan produk lembaga pendidikan dengan lembaga pendidikan yang lain, memberikan penilaian lebih pada masyarakat dengan produk yang ditawarkan, serta menstabilkan eksistensi dan kebermaknaan lembaga pendidikan di masyarakat. 
Dalam merumuskan strategi pemasaran, hendaknya memperhatikan apa saja yang menjadi harapan dan kebutuhan peserta didik dengan cara mendengarkan keluhan-keluhan peserta didik dan mencari solusi yang dapat memperbaiki strategi pemasaran yang sudah ada. Dengan langkah-langkah kegiatan tersebut, madrasah dalam mencapai keseimbangan dalam operasionalisasi pengajaran dalam kondisi memperebutkan pasar dari banyak penyelenggara sekolah. Dengan demikian, masalah madrasah yang kekurangan murid diharapkan tidak terjadi lagi.

\section{REFERENSI}

Alma, B. (2005). Pemasaran Stratejik Jasa Pendidikan. Alfabeta.

Amstrong, M. (2003). Strategic Human Resource Management. Terjemahan Atit Cahayani. PT Bhuana IImu Populer.

Anam, K. (2013). Strategi Pemasaran dan Implementasinya dalam Lembaga Pendidikan. Ta'allum: Jurnal Pendidikan Islam, 1(2), 159-170.

https://doi.org/10.21274/taalum.2013.1.2.159-170

Asmani, J. M. (2015). Manajemen Efektif Marketing Sekolah Pertama. DIVA Press.

Faizin, I. (2017). Strategi Pemasaran Jasa Pendidikan dalam Meningkatkan Nilai Jual Madrasah. Madaniyah, 7(2), 261-283.

https://journal.stitpemalang.ac.id/index.php/madaniyah/article/view/15/1

Fattah, N. (2017). Landasan Manajemen Pendidikan. Remaja Rosda Karya.

Giligan, C., \& Wilson, R. M. S. (2009). Strategic Marketing Planning. Elseiver.

Hafidhuddin, D., \& Tanjung, H. (2003). Manajemen Syari'ah dalam Praktik. Gema Insani Press.

Hooley, G., Piercy, N. F., Nicouloud, B., \& Rudd, J. M. (2008). Marketing Strategy and Competitive Positioning. Prentice Hall.

Hurriyati, R. (2010). Bauran Konsumen dan Loyalitas Konsumen. Alfabeta.

Khasanah, A. (2015). Pemasaran Jasa Pendidikan Sebagai Strategi

Peningkatan Mutu Di Sd Alam Baturraden. El-Tarbawi, 8(2), 161-176.

https://doi.org/10.20885/tarbawi.vol8.iss2.art4

Kotler, P. (1997). Manajemen Pemasaran; Analisis, Perencanaan, Implementasi dan Kontrol,. Prehallindo.

Kotler, P. (2000). Marketing Management (The Millennium Edition). Prentice Hall.

Kotler, P., \& Kevin, L. K. (2012). Marketing Management. Pearson Pretice Hall.

Minarti, S. (2012). Manajemen Sekolah (Mengelola Lembaga Pendidikan Secara Mandiri). Ar-Ruuz Media.

Muhaimim, M., Suti'ah, S., \& Prabowo, S. L. (2011). Manajemen Pendidikan (Aplikasinya dalam Penyusunan Rencana Pengembangan Sekolah/Madrasah). Kencana Premada Media Grup.

Mundir, A. (2015). Strategi Pemasaran Jasa Pendidikan Madrasah. MALIA: Jurnal Ekonomi Islam, 7(1), 27-40. https://doi.org/10.35891/ml.v7i1.369

Sagala, S. (2007). Manajemen Strategik Dalam Peningkatan Mutu Pendidikan. Alfabeta.

Sudiarta, I. N. (2011). Strategi Pemasaran: Mengintegrasikan Konsep Pemasaran Pariwisata, Gaya Hidup Konsumen dan Manajemen Destinasi Pariwisata Menuju Kualitas Pengalaman Berkelanjutan. Jurnal IImiah 
I. Fathurrochman, Endang, D. Bastian, M. Ameliya, A. Suryani

Manajemen Dan Akuntansi, 16(2), 1-16.

http://erepo.unud.ac.id/id/eprint/7209/

Suprapti, N. W. S. (2010). Perilaku Konsumen: Pemahaman Dasar dan

Aplikasinya dalam Strategi Pemasaran. Universitas Udayana.

Swastha, B., \& Irawan, I. (2008). Menejemen Pemasaran Modern. Liberty.

Tedjasatesan. (2001). Strategi Pemasaran dan Manajemen Pemasaran Jasa. Alfabeta.

Wibowo. (2006). Manajemen Perubahan. PT Raja Grafindo Persada.

Winardi, J. (2001). Motivasi dan Pemotivasian dalam Manajemen. PT Raja Grafindo Persada.

Zeithaml, V. A., Bitner, M. J., \& Gremler, D. D. (2013). Services Marketing: Integrating Customer Focus Across The Firm. Mc.Graw-Hill. 